\title{
Physiological and Genetic Variations of Amorphophallus variabilis in Bojonegoro based on Glucomannan Content, Calcium Oxalate and RAPD Markers
}

\author{
Achmad Yogi Pambudi ${ }^{*}$, Nunung Harijati ${ }^{2}$, Estri Laras Arumingtyas ${ }^{3}$ \\ ${ }^{1}$ Master Program of Biology, Faculty of Mathematics and Natural Sciences, University of Brawijaya, Malang, Indonesia \\ ${ }^{2}$ Department of Biology, Faculty of Mathematics and Natural Sciences, University of Brawijaya, Malang, Indonesia
}

\begin{abstract}
This study had purpose to determine the glucomannan and calcium oxalate content in 7 variants of $A$. variabilis and their genetic relationships based on RAPD markers. Amorphophallus variabilis Tuber samples were taken from Karangdowo village, Sumberrejo Sub-district, Bojonegoro District, East Java. Each variant was analyzed for its glucomannan content by the spectrophotometric method using 3,5-DNS reagents and calcium oxalate by the $0.1 \mathrm{~N}$ KMnO4 titration method. Leaf DNA extraction was carried out using the CTAB method. Relationship analysis used RAPD markers with 5 primers (OPA-11, OPC-04, OPU-06, OPC-07, and OPN-1). The obtained data were analyzed using the Numerical Taxonomy and Multivariate System (NTSYS-pc) version 2.1. The grouping of glucomannan content or oxalium oxalate used hierarchical clustering analysis (SPSS 16.0). This research found that the calcium oxalate content in seven variants of $A$. variabilis ranged from 0.01 to $0.03 \mathrm{~g}$, where the variant with the lowest calcium oxalate is $V 6$ with a value of $0.01 \mathrm{~g}$ and the highest is the V7 variant with a value of $0.03 \mathrm{~g}$, while the glucomannan content ranges from 9 $38 \%$. The highest glucomannan content is V3, while the lowest is V6. Phenograms formed based on RAPD markers showed the formation of two groups of $A$. variabilis. Group one has two subgroups. Subgroup one consists of variants V1 and V4, while subgroup two consists of V6 and V7. Meanwhile, the second group consists of variants V2, V3, and V5. The seven variant grouping pattern of $A$. variabilis based on RAPD markers has no similarity to the grouping pattern based on the results of glucomannan or calcium oxalate analysis.
\end{abstract}

Keywords: A. variabilis, Calcium oxalate, Glucomannan, RAPD, Variant.

\section{INTRODUCTION}

Amorphophallus variabilis is a native plant of Java, Madura, and Kangean Islands, Indonesia. This plant is located at 700 to $900 \mathrm{~m}$ above sea level. Amorphophallus variabilis is locally called white iles-iles or cocooan oray in Sundanese. Local people are often confused by the terms iles-iles (yellow) for $A$. muelleri and suweg for $A$. paeoniifolius Dennst. Nicolson. Morphologically, A. variabilis does not have an aerial bulb in rachis, unlike $A$. muelleri [1].

Amorphophallus variabilis is one of Java's traditional foods. $A$. variabilis bulbs contain about $50 \%$ glucomannan, so they suitable to be used as raw materials in the food industry. Since the 1960s, rice plants became popular in Indonesia, therefore the utilization of tuber crops, including Amorphophallus species, decreased [1]. Besides glucomannan, Amorphophallus also contain calcium oxalate, which is a dicarboxylic acid with two $\mathrm{C}$ atoms in each carboxylic group. Consumption of oxalate in large quantities can cause kidney stones [2]. In

\footnotetext{
* Correspondence address:

Achmad Yogi Pambudi

Email : yogyaahmad5@gmail.com

Address : Dept. Biology, University of Brawijaya, Veteran Malang 65145.
}

addition, Calcium oxalate is dangerous for human health because this substance is anti-nutrient, which affects the unavailability of calcium in the body. Also, it can cause mechanical abrasion in the digestive tract and various fine tubules found in the kidneys [3].

Bojonegoro Regency is one area at East Java that has a lot of iles-iles (Amorphophallus variabilis) plants. Bojonegoro is located at $112^{\circ} 25^{\prime}-112^{\circ} 09^{\prime}$ East Longitude and $6^{\circ} 59^{\prime}-7^{\circ} 37^{\prime}$ South Latitude. Topographically, Bojonegoro area has land with a relatively flat slope. Existing data of Bojonegoro Regency showed that $91.26 \%$ of land in this region has a slope between $0-15 \%$. The surface area of Bojonegoro Regency is relatively low, which is located between 25-500 $\mathrm{m}$ above sea level. Based on the location of the topography, Bojonegoro is one of the suitable areas for A.variabilis habitat. A.variabilis grows well in the area with condition $100-700 \mathrm{~m}$ above sea level [4].

From field observations, we found morphological variations of $A$. variabilis in Bojonegoro, especially in the petiole, both color and pattern of its skin. Pattern variations of petiole skin (Corak) may affect glucomannan content [5]. As a member of the Araceae family, glucomannan content of Amorphophallus sp has varying levels depending on the species. 
Therefore, it was necessary to determine both glucomannan and calcium oxalate content among $A$. variabilis variants in Bojonegoro with the expectation to find candidate variant which has high glucomannan content as well as low calcium oxalate content.

The existence of petiole pattern's skin variation from $A$. variabilis reflects genetic diversity. However, the morphology pattern sometime reflect its ecotype, so it is difficult to know the true diversity within a species. Therefore, we used molecular markers to determine the genetic diversity of plants that have a close genetic relationship [6]. Molecular markers have been used to study variation even among the species members of Araceae, such as molecular analysis, with RAPD markers on the Amorphophallus genus. Amorphophallus species that have been successfully analyzed by RAPD markers are A. titanium [7]. In this study, molecular analysis was performed with RAPD markers to determine whether the grouping of A.variabilis based on RAPD markers was similar to grouping based on glucomannan content or calcium oxalate content.

\section{MATHERIAL AND METHOD}

\section{Preparation of Glucomannan Analysis}

Amorphophallus variabilis tubers used in this research were taken from Bojonegoro, East Java. Glucomannan analysis followed the Chua Method [8], using 3.5 DNS reagents. This reagent will give a yellow color that is proportional to the amount of glucomannan. 3,5-Dinitro Salisilic Acid reagent is made by mixing solution $A$ and solution B. Solution A was prepared by mixing phenol $(0.7 \mathrm{~g}), 10 \% \mathrm{NaOH}(1.5 \mathrm{~mL})$, aquadest $(5$ $\mathrm{mL})$, and sodium bisulphite $(0.7 \mathrm{~g})$. Solution B was prepared by mixing potassium sodium tartrate $(22.5 \mathrm{~g}), 10 \% \mathrm{NaOH}(30 \mathrm{~mL})$, and $1 \%$ dinitro salicylic acid ( $88 \mathrm{~mL})$.

\section{Extract and Hydrolyzate of Glucomannan}

Glucomannan extract is made by dissolving $0.2 \mathrm{~g}$ grind tuber-flesh in $100 \mathrm{~mL}$ of buffer solution (formic acid-sodium hydroxide), stirred for 4 hours then centrifuged at $4000 \mathrm{rpm}$ for 20 minutes at $25^{\circ} \mathrm{C}$; the white liquid produced is glucomannan extract. Glucomannan hydrolyzate was prepared by mixing $5 \mathrm{~mL}$ of glucomannan extract with $2.5 \mathrm{~mL}$ of $3 \mathrm{M}$ Sulfuric Acid, heated in boiling water bath for 1.5 hours, then add $2.5 \mathrm{~mL}$ of $6 \mathrm{M} \mathrm{NaOH}$ and dilute to $25 \mathrm{~mL}$ using aquadest. A total of $2 \mathrm{~mL}$ of glucomannan extract or glucomannan hydrolyzate added with $1.5 \mathrm{~mL}$ of 3.5 DNS reagents, vortexes to homogenize. The absorbance of the solution was measured using a spectrophotometer with a wavelength of 550 $\mathrm{nm}$. Glucomannan content determined according to the following formula.

$$
\text { glucomanan content }(\%)=\frac{\varepsilon(5 T-T 0) \times 50}{m x(1-W) \times 100} \times 100
$$

\section{Description:}

$\varepsilon$ : The ratio of glucose molecular weight and mannan residues in glucomannan to glucose and mannan molecular weights produced after hydrolysis, $\varepsilon=0.9$

$T$ : The amount $(\mathrm{mg})$ of glucose in glucomannan hydrolyzate obtained from a standard curve

$T_{0}$ : The amount (mg) of glucose in glucomannan extract obtained from the standard curve

$m$ : Sample mass (g)

W : Moisture content of the sample

\section{Calcium oxalate}

Calcium oxalate content determined through three stages, 1) Digestion, at this stage, 2 g grindtuber mixed with $190 \mathrm{~mL}$ of distilled water in a $250 \mathrm{~mL}$ measuring flask, $10 \mathrm{~mL}$ of $6 \mathrm{M} \mathrm{HCl}$ was added, and the suspension digested at $100^{\circ} \mathrm{C}$ for 1 hour, then cooled and added distilled water to $250 \mathrm{~mL}$ before filtration. 2) Precipitation, the oxalate of the filtrate from every $125 \mathrm{~mL}$ of the suspension was added 4 drops of the red methyl indicator, then added $\mathrm{NH} 4 \mathrm{OH}$ to obtain $\mathrm{PH}$ 4-4.5. Each part was heated at $90^{\circ} \mathrm{C}$, then cooled and filtered to remove iron-sulfur ions. The filtration product reheated at $90^{\circ} \mathrm{C}$, when the solution was stirred with a stirrer, $10 \mathrm{~mL} \mathrm{CaCl} 5 \%$ was added. After heating, then cooled overnight at $5^{\circ} \mathrm{C}$. The solution then centrifuged with a speed of 2500 rpm for 5 minutes. Subsequently, supernatant removed and precipitation result dissolved in 10 $\mathrm{mL}$ of $20 \% \mathrm{H}_{2} \mathrm{SO}_{4}$ solution. 3) Permanganate titration $\left(\mathrm{KMnO}_{4}\right)$, the resulting filtrate was made up to $300 \mathrm{~mL}$ with water. $125 \mathrm{~mL}$ of aliquot filtrate heated to a slight boil, then titrated with standard $0.1 \mathrm{~N} \mathrm{KMnO4}$ standard until produced a faded- pink color. The color was maintained for 30 seconds [9]. The calcium oxalate content was calculated using the following formula.

Calcium oxalate $(g)=\frac{V x N \text { Oxalate } x \text { Mr Calcium Oxalate }}{1000}$

Description:

$\mathrm{V}$ : the titration volume or titer volume $=$ volume of $\mathrm{KMNO}_{4}(\mathrm{~mL})$ used in the titration until equilibrium reached or the equivalent point reached.

$\mathrm{N}$ : stated that the normality of calcium oxalate, which has been standardized

$\mathrm{Mr}$ (calcium oxalate) was 128.

DNA Isolation and Random Amplified
Polymorphic DNA (RAPD) Analyzis
DNA isolated with the Doyle and Doyle CTAB method [10]. Leaf of $A$. variabilis was taken fresh 
and weighed 0.1-0.2 g, and crushed using mortalpestle. Before grinding, the leaf sample poured with enough liquid nitrogen. The results were transferred into the Eppendorf tube (hereinafter referred to as Epitube) and added $700 \mu \mathrm{L}$ CTAB buffer then vortex. Epitube was incubated at $65^{\circ} \mathrm{C}$ in a water bath for 10 minutes.

After the incubation time fulfilled, extraction performed by adding phenol ( $\mathrm{PCl}$ ) as much as 700 $\mu \mathrm{L}$ (vortex). Epitube which has received the addition of $\mathrm{PCl}$, centrifuged at $13000 \mathrm{rpm}$ for 10 minutes at $4^{\circ} \mathrm{C}$. Then the supernatant transferred to a new Epitube and the $\mathrm{Cl}$ was added to the same volume as the supernatant volume, vortexed. The extraction was continued with centrifuged $13000 \mathrm{rpm}$ for 5 minutes at $4^{\circ} \mathrm{C}$, the supernatant was discarded carefully so that only pellets remained. DNA (pellets) was added with 0.1 volume of ammonium acetate and 2.5 volumes of absolute ethanol (vortex). The epitube containing DNA was then incubated at $20^{\circ} \mathrm{C}$ overnight. The following day the solution was centrifuged at $12000 \mathrm{rpm}$ for 15 minutes at $4^{\circ} \mathrm{C}$. Pellets washed with $70 \%$ cold alcohol with centrifuged at $12000 \mathrm{rpm}$ for 15 minutes at $4^{\circ} \mathrm{C}$. The pellets were dissolved in $20 \mu \mathrm{L}$ TE solution (1 $\mathrm{mM}$ Tris $\mathrm{HCl} \mathrm{pH} \mathrm{8,} 0.1 \mathrm{mM}$ ) for RAPD analysis.

The genomic DNA of $A$. variabilis amplified using 5 RAPD primers (Table 2), which based on previous studies [11]. The reaction mixture of

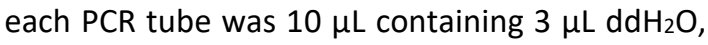
$1 \mu \mathrm{L}$ primary RAPD 10 pmol, $5 \mu \mathrm{L} 2 \mathrm{x}$ PCR Intron master mix, $1 \mu \mathrm{L}$ DNA template $50 \mathrm{ng}$. PCR reaction was carried out for 45 cycles using a thermocycler (Takara). Initial denaturation was done at $94^{\circ} \mathrm{C}$ for 5 minutes, then followed by 45 cycles namely denaturation of $94^{\circ} \mathrm{C}$ for 1 minute, annealing $36^{\circ} \mathrm{C}$ for 1 minute, extension $72^{\circ} \mathrm{C}$ for 2 minutes. The final extension is $72^{\circ} \mathrm{C}$ for 4 minutes and cooling at $4^{\circ} \mathrm{C}$ for 30 minutes [7].

Table 1. RAPD primers used in research

\begin{tabular}{cll}
\hline No. & Primers Code & Nitrogen base sequence $\mathbf{5}^{\prime} \mathbf{- \mathbf { 3 } ^ { \prime }}$ \\
\hline 1 & OPA-11 & CAATCGCCGT \\
3 & OPC-04 & CCGCATCTAC \\
4 & OPU-06 & ACCTTTGCGG \\
5 & OPC-07 & CACACTCCAG \\
8 & OPN-18E & AAGGTGAGGTCA \\
\hline
\end{tabular}

Data Analyzis

Glucomannan or calcium oxalate data were analyzed by analysis of variance (ANOVA) using the SPSS program followed by the Tukey test with $p<0.05$ significant. Before conducting the ANOVA test, the homogeneity test was carried out by the Levene test, and the normality of the data was carried out by the Kolmogorov-Smirnov test. Glucomannan or calcium oxalate data grouping performed using Hierarchy Clustering with SPSS program.

The DNA band profile resulting from PCR amplification using RAPD primers converted into binary data with two values, namely one (1) for the presence of DNA bands and zero (0) for the absence of DNA bands. Only the clear band counted. Binary data was used to generate binary data matrices using the Numerical Taxonomy and Multivariate System (NTSYS-pc) version 2.1. The binary data matrix then reduced to a genetic similarity matrix between $A$. variabilis using Jaccard's similarity coefficient. The genetic similarity matrix created using Similarity for Quantitative Data (SIMQUAL). Based on the genetic similarity matrix, Cluster Analysis performed using the Unweighted Pair-Group Method with Arithmetic Average (UPGMA) by the Sequential Agglomerative Hierarchical Nested Cluster Analysis (SAHN) sub-program. The results of UPGMA grouping analysis were made in a cladogram using a tree-display, which is a sub-program Graphics NTSYS-pc Program [12].

\section{RESULT AND DISCUSSION}

A. variabilis, which found in the Bojonegoro District, has variations in petiole skin color called corak of both color and shape. Petiole skin color variations of seven variants of $A$. variabilis that found included dark green, light green, brownishgreen and blackish green, while the colors of the corak were white, brownish, greenish-white and black and white. The shape of the corak of the seven variants is round, oval, and elliptical (Table 2, Fig. 1). Variations that arise in the skin color of the petiole and the color of the corak thought to be due to a combination of pigment levels such as chlorophyll, $\beta$-carotene and anthocyanin [13].

Table 2. A. variabilis variation

\begin{tabular}{|c|c|c|c|}
\hline Variant & $\begin{array}{l}\text { Petiole } \\
\text { color }\end{array}$ & $\begin{array}{l}\text { Pattern } \\
\text { color }\end{array}$ & Shape of corak* \\
\hline V1 & Dark green & White & Irregular round \\
\hline V2 & Dark green & White & Ellipse and oval \\
\hline V3 & $\begin{array}{l}\text { Brownish } \\
\text { green }\end{array}$ & Brownish & $\begin{array}{l}\text { Small round and } \\
\text { tight }\end{array}$ \\
\hline V4 & Light green & White & $\begin{array}{l}\text { Ellipse and big } \\
\text { enough }\end{array}$ \\
\hline V5 & Light green & $\begin{array}{l}\text { Greenish } \\
\text { white }\end{array}$ & $\begin{array}{l}\text { Round irregular } \\
\text { and tight }\end{array}$ \\
\hline V6 & $\begin{array}{l}\text { Brownish } \\
\text { green }\end{array}$ & Light green & $\begin{array}{l}\text { Large round and } \\
\text { not tight }\end{array}$ \\
\hline V7 & $\begin{array}{l}\text { Blackish } \\
\text { green }\end{array}$ & $\begin{array}{l}\text { Black and } \\
\text { white }\end{array}$ & $\begin{array}{l}\text { Small round and } \\
\text { tight }\end{array}$ \\
\hline
\end{tabular}

*pattern-architecture of skin surface 


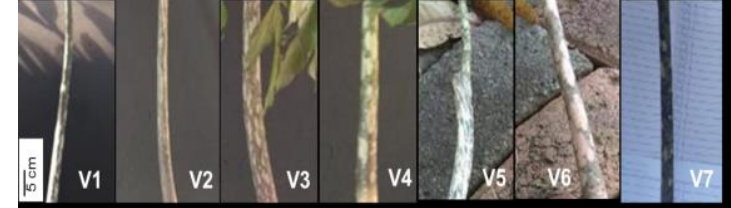

Figure 1. V1-V7: Variation of $A$. variabilis

Tubers are a means of vegetative propagation of plants and plant parts that used as storage for food reserves [14]. Tuber seeds used in this study were taken from the field with an average weight of 70.5-110.5 g. Then the tubers were planted until the aerial shoots part fall. After the aerial shoots fall, the tubers were harvested. Tuber yields of these plants weigh about 196.28-334 g, diameters range from $86.37-115.82 \mathrm{~mm}$ and tuber thickness ranges from $42.82-65.18 \mathrm{~mm}$ (Table 3).

Diameter and tuber weight of $A$. variabilis correlated very significantly with tuber glucomannan content. It meant that tuber diameter and tuber weight of harvest will influence the increase or decrease of tuber glucomannan content. The heavier tubers in $A$. variabilis may contain greater glucomannan [15]. In this study, however, heavy tubers and wide diameters, for example variant 1 (V1) or variant 2 (V2), did not contain high glucomannan (Table 3).

Table 3. Tuber weight, diameter, and thick of $A$. variabilis variant

\begin{tabular}{cccc}
\hline Variant & $\begin{array}{c}\text { Tuber } \\
\text { weight }(\mathbf{g})\end{array}$ & $\begin{array}{c}\text { Tuber diameter } \\
\text { (mm) }\end{array}$ & $\begin{array}{c}\text { Tuber thick } \\
\text { (mm) }\end{array}$ \\
\hline V1 & 304.60 & 115.82 & 48.03 \\
V2 & 334.56 & 106.54 & 65.18 \\
V3 & 286.24 & 99.12 & 55.47 \\
V4 & 253.36 & 93.63 & 56.28 \\
V5 & 196.28 & 86.37 & 42.82 \\
V6 & 305.88 & 102.46 & 60.89 \\
V7 & 234.65 & 92.24 & 59.25 \\
\hline
\end{tabular}

Glucomannan is a type of special polysaccharides found in Amorphophallus tubers. The results of glucomannan extraction in seven variants of $A$. variabilis showed different glucomannan contents, ranging from $10-38 \%$. The highest glucomannan content found in variant V3 of $A$. variabilis for $38 \%$ and the lowest in variant V6, which was $9 \%$ (Fig. 2). In summary, the glucomannan content of seven variants grouped into three categories, namely low, medium, and high categories. Low category comes from variants V2, V4, V5, and V6 (9-12\%). Medium categories come from V1 and V7 (15$19 \%)$. High category consists of V3 (38\%).

Mekkerdchoo et al. [16] used the same method (assay using 2,5-DNS) also grouped the glucomannan content of six Amorphophallus species (A. muelleri, A. krausei, A. kachiensis, $A$. bulbifer, $A$. Xiei, and $A$. corrugatus) into three groups: low (16\%), moderate (22-24\%), and high (32-42\%). Whereas, Dini [5] grouped the glucomannan content of 8 variants of $A$.variabilis into low (16\%), moderate (22-24\%), and high (3242) using a different method of centrifugation which was an adaptation of the Tatirat and Charoenrein method [17].

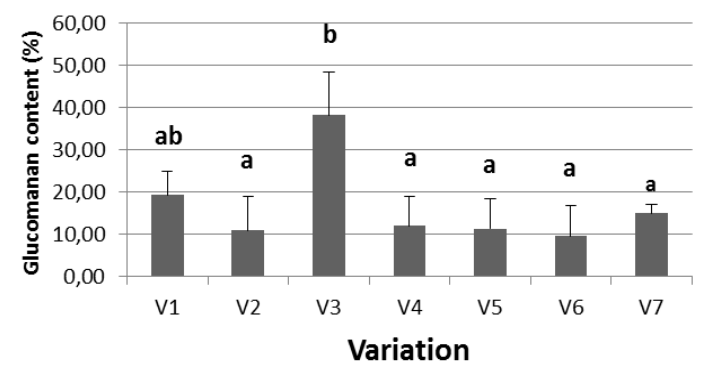

Figure 2. Glucomannan content in seven variants of $A$. variabilis, V1-V7: seven variants of $A$. variabilis. Note: the same notation shows no significant difference in the 0.05 Tukey test.

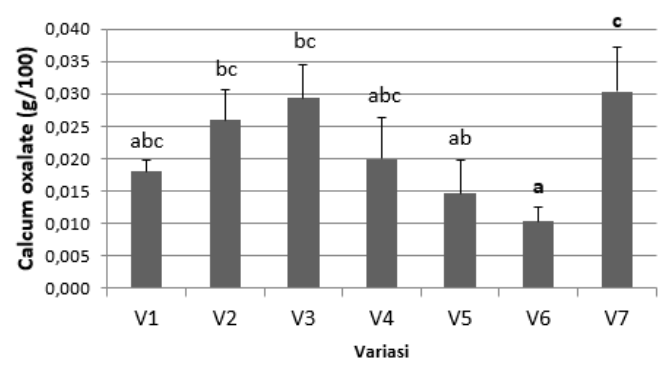

Figure 3. Calcium oxalate content in seven variants of A. variabilis, V1-V7: seven variants of $A$. variabilis. Note: the same notation shows no significant difference in the 0.05 Tukey test

The calcium oxalate content of seven variants of $A$. variabilis showed variants $\mathrm{V} 1, \mathrm{~V} 4, \mathrm{~V} 5$, and V6 have the same letter notation (Fig. 3). Meanwhile, the lowest V4 calcium oxalate content was significantly proven significantly different from V7, which had the highest oxalate content as indicated by different letter notation (c). The calcium oxalate content in $A$. variabilis variant V3 was not significantly different from variant V1 (b). Based on the picture above, it was known that the $A$. variabilis tuber contains different calcium oxalate content, ranging from 0.01 to $0.03 \mathrm{~g}$. In these results, the V 6 variant has the lowest oxalate content, while the $\mathrm{V} 7$ variant had the highest one, which was $0.03 \mathrm{~g}$. These results showed that calcium oxalate was still safe for consumption (0.60-1.25 g per day) [18].

RAPD on seven variants of Amophophallus variabilis using OPA-11, OPC-04, OPU-06, OPC-07, and OPN-18E primers produced 24 amplicons 
ranging from $500 \mathrm{bp}$ to $4000 \mathrm{bp}$. Sixteen bands $(61.54 \%)$ were polymorphic bands, and ten bands $(38.47 \%)$ were monomorphic. A relatively high level of polymorphism with RAPD markers showed a high mark index. The highest number of polymorphic bands (4) was in the OPN-18E primer, while the lowest number (2) was in the OPU-06 primer (Table 6). The high band polymorphism in this study showed the high genetic diversity in variants of $A$. variabilis. Research by Poerba and Martanti [11] on Amophophallus muelleri using RAPD also showed genetic diversity. By using five primers, a total of 42 amplicons obtained, 29 bands (60.05\%) were polymorphic, and 13 bands (30.95\%) were monomorphic.

\begin{tabular}{llll}
\multicolumn{4}{c}{ Table 6. RAPD amplification band } \\
\hline Primer & $\begin{array}{c}\text { Polymorphic } \\
\text { bands }\end{array}$ & $\begin{array}{c}\text { Monomorphic } \\
\text { bands }\end{array}$ & $\begin{array}{c}\text { Total } \\
\text { band }\end{array}$ \\
\hline OPA-11 & 3 & 1 & 4 \\
OPC-04 & 4 & 4 & 8 \\
OPU-06 & 4 & 2 & 6 \\
OPC-07 & 3 & 1 & 4 \\
OPN- & 4 & 0 & 4 \\
18E & & & $26(100 \%)$ \\
\hline Total & $16(61.54(\%)$ & $10(38.46 \%)$ & \\
\hline
\end{tabular}

Phenograms formed based on RAPD markers showed the formation of two groups of $A$. variabilis-variant. Group one has two subgroups. Subgroup one consists of variants V1 and V4 with a similarity coefficient 0.65 , while subgroup two consists of V6 and V7 with a similarity coefficient 0.72 . Group two consisted of $\mathrm{V} 2, \mathrm{~V} 3$, and $\mathrm{V} 5$ variants with a 0.68 similarity coefficient (Fig. 4).

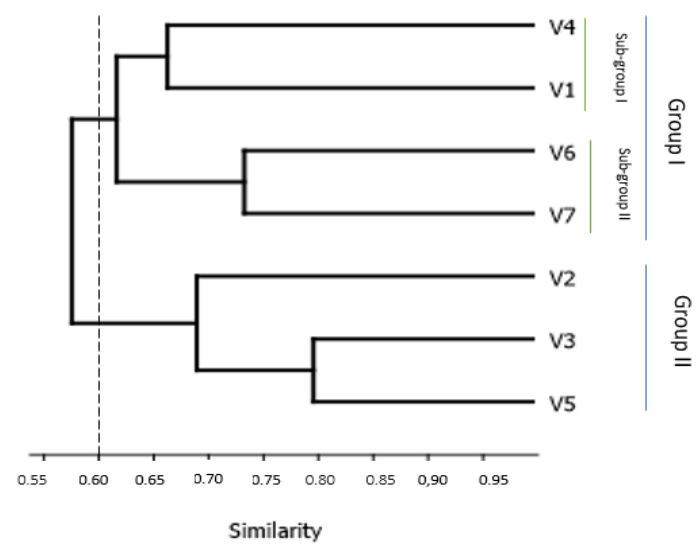

Figure 4. Phenogram $A$. variabilis based on RAPD markers

The results of grouping the seven variants of A. variabilis based on the RAPD markers did not show similarity in grouping patterns based on glucomannan or calcium oxalate content (Fig. 5 and 6). For example, in glucomannan, V3 and V7 formed one group, whereas, in phenogram based on RAPD markers, V3 grouped with V5, and V7 formed a group with V6. In calcium oxalate, V3 not only grouped with V7 but also with V2, V6, and V1. It can occur due to various factors, including the result of random amplification of primary RAPD that does not lead to a particular trait. One weakness of the RAPD marker for amplicon identity is unknown, unless the study is supported by pedigree analysis. From the results of the study, it can be said that the grouping based on RAPD markers cannot be used to predict groupings based on glucomannan or calcium oxalate content. Nevertheless, the results of grouping based on RAPD indicated that the seven variants of $A$. variabilis do indeed vary, the genomes were divided into two large groups.

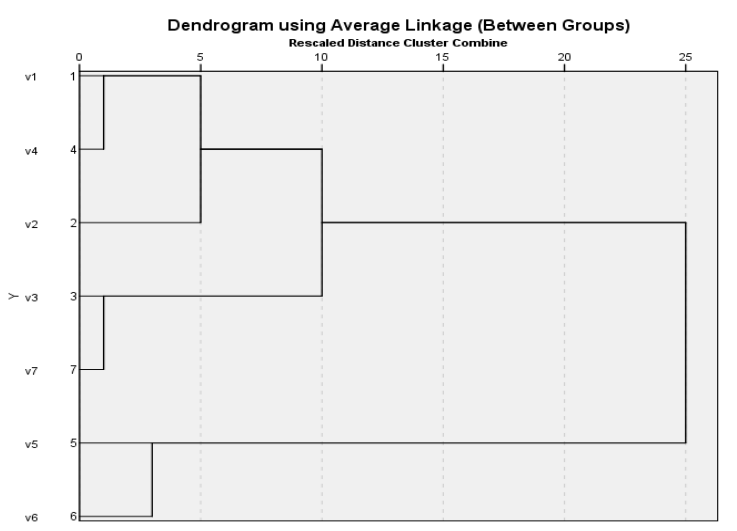

Figure 5. Glucomannan phenogram A. variabilis based on Hierarchy Clustering

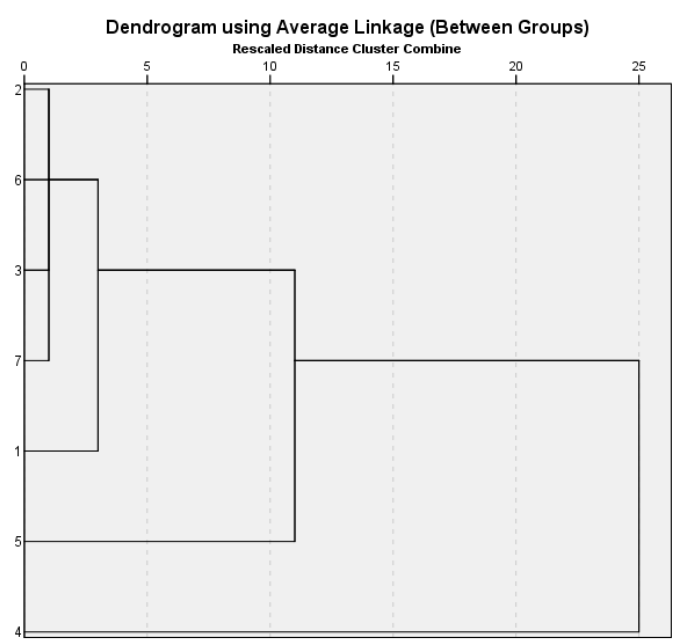

Figure 6. Calcium oxalate phenogram $A$. variabilis based on Hierarchy Clustering

\section{CONCLUSION}

The conclusion obtained from this study is that the glucomannan content in seven variants of $A$. variabilis ranges from $9-38 \%$. Classification of variants based on glucomannan content is divided into three categories, namely low, 
consisted of variants V2, V4, V5, and V6 with glucomannan content of $11-12 \%$. The medium category consists of variants V1 and V7 with glucomannan content of 11,12 , and $15 \%$. The high category consists of variants of V3 with $38 \%$ glucomannan content, while for the content of calcium oxalate contained in seven variants of $A$. variabilis ranged from 0.01 to $0.03 \mathrm{~g}$. The variant with the lowest calcium oxalate is V6 with a value of $0.01 \mathrm{~g}$, and the highest is the variant V7 with a value of $0.03 \mathrm{~g}$. The range of calcium oxalate content is in a good range for health.

Phenograms formed based on RAPD markers showed the formation of two groups of $A$. variabilis. Group one has two subgroups, subgroups one consisted of variants V1 and V4, while subgroup two consists of V6 and V7. Group two consists of variants V2, V3, and V5. There is no similarity between the grouping of seven variants of $A$. variabilis based on variations in glucomannan or calcium oxalate content with grouping based on RAPD markers.

\section{REFERENCES}

[1] Santosa, E., N. Sugiyama, S. Hikosaka, T. Takano. 2012. Genetic variations of Amorphophallus variabilis Blume (Araceae) in Java using AFLP. Jurnal Agronomi Indonesia. 40(1). 62-68.

[2] Franceschi, V.R., P.A. Nakata. 2005. Calcium oxalate in plants: formation and function. Annu. Rev.Plant Biol. 56. 41-71.

[3] Brown, D. 2000. Aroids: plants of the arum family, $2^{\text {nd }}$ Ed. Timber Press, Portland. Oregon.

[4] Yuzammi, A. Kurniawan, N.P.S. Asih, I. Erlinawati, W. Hetterscheid. 2017. The Amorphophallus of Indonesia. Centre for Plant Conservation-Botanic Gardens, LIPI.

[5] Dini, Z.Z. 2017. Variasi kandungan glukomanan dan hubungan kekerabatan menggunakan penanda RAPD pada berbagai varian Amorphophallus Variabilis Blume asal Tuban. Bachelor Thesis. Brawijaya University. Malang.

[6] Brown, E.J. 1991. Assesment of RAPD markers to detect genetic diversity in rice plants. Crops Sci. 3.670-675.

[7] Poerba, Y.S, Yuzammi. 2008. Pendugaan keragaman genetik Amorphophallus titanium Becc. berdasarkan marka Random Amplified Polymorphic DNA. Biodiversitas. 9(2). 103-107.

[8] Chua, M., K. Chan, T.J. Hocking, P.A. Williams, C.J. Perry, T. C. Baldwin. 2012.
Methodologies for the extraction and analysis of konjac glucomannan from corms of Amorphophallus konjac K. Koch. Carbohydr. Polym. 87. 2202-2210.

[9] Iwuoha, C.I., F.A. Kalu. 1995. Calcium oxalate and physico-chemical properties of cocoyam (Colocasia esculenta and Xanthosoma sagittifolium) tuber flours as affected by processing. Food Chem. 54. 6166.

[10] Doyle, J.J., J.L. Doyle. 1990. Isolation of plant DNA from fresh tissue. Focus. 12. 1315.

[11] Poerba, Y.S., D. Martanti. 2008. Keragaman genetik berdasarkan marka Random Amplified Polymorphic DNA pada Amorphophallus muelleri Blume di Jawa. Biodiversitas. 9(4). 245-249.

[12] Rohlf, F.J. 2000. NTSYSpc Numerical Taxonomy and Multivariate Analysis system Version 2.1. Exter Publication. New York.

[13] Salisbury, F.B., C.W. Ross. 1992. Fisiologi tumbuhan, $2^{\text {nd }} E d$. ITB. Bandung.

[14] Aksenova, N.P., L.I. Sergeeva, T.N. Konstantinova, S.A. Golyanovskaya, O.O. Kolachevskaya, G.A. Romanova. 2013. Regulation of potato tuber dormancy and sprouting. Russian J. Plant Physiol. 60. 301312.

[15] Ambarwati, E., R.H. Murti. 2001. Analisis korelasi dan koefisien lintas sifat-sifat agronomi terhadap komposisi kimia umbi iles-iles (Amorphophallus variabilis). IImu Pertanian. 8(2). 55-61.

[16] Mekkerdchoo, O., C. Borompichaichartkul, A.L. Perrigo, G. Srzednicki, C. Prakitchaiwattana, A. Antonelli. 2016. Tracing the evolution and economic potential of Konjac Glucomannan in Amorphophallus species (Araceae) using molecular phylogeny and RAPD markers. Phytotaxa. 282(2). 81-106.

[17] Tatirat, O., S. Charoenrein. 2011. Physicochemical properties of konjac glucomannan extracted from konjac flour by a simple centrifugation process. LWT - Food Sci. Technol. 44(10). 2059-2063.

[18] Mawarni, R.T., S.B. Widjanarko. 2015. Penggilingan metode ball mill dengan pemurnian kimia terhadap penurunan oksalat tepung porang. Jurnal Pangan dan Agroindustri. 3(2). 571-581. 